Nalar: Jurnal Peradaban dan Pemikiran Islam

Vol. 2, No. 1, Juli 2018

\title{
Micro Hijabers Celebrity: Membentuk Identitas dengan Update Self-Story via Instagram (Kasus Dian Pelangi)
}

\author{
Khairul Arief Rahman ${ }^{1}$, Isti Khomalia ${ }^{2}$ \\ ${ }^{1}$ Universitas Gadjah Mada, Yogyakarta, Indonesia \\ ${ }^{2}$ Universitas Islam Negeri Sunan Kalijaga Yogyakarta, Indonesia \\ ${ }^{1}$ khairularief44@gmail.com, ${ }^{2}$ istymifthab@gmail.com
}

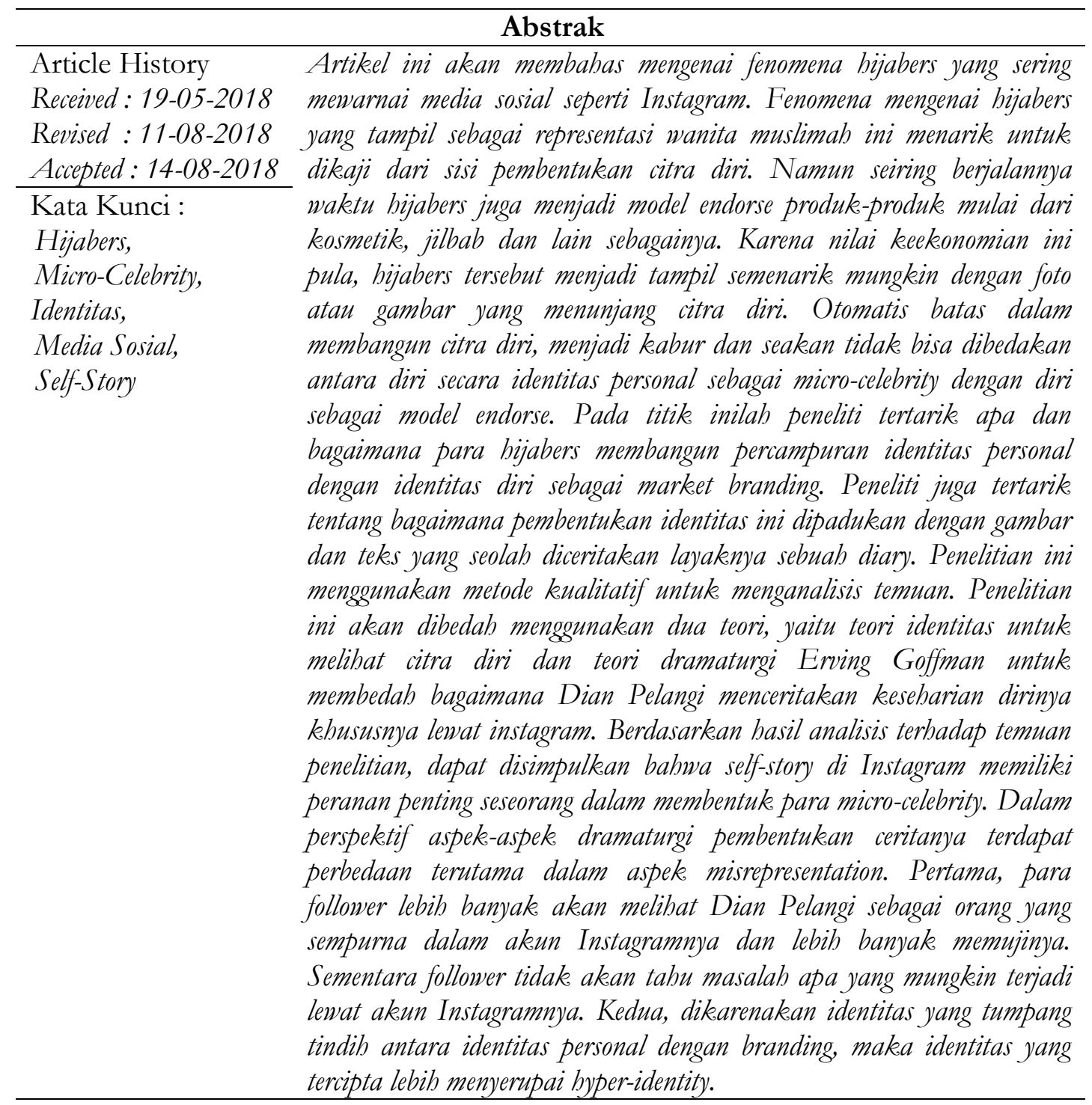

\section{Pendahuluan}

Jejaring media sosial sepertinya akan melahirkan fenomena-fenomana baru bersifat global maupun lokal. Ini ditandai dengan beragamnya jenis inovasi, pemikiran, ide yang tersebar di dunia maya tanpa kontrol. Namun dari kesemua itu, eksistensi menjadi hal yang utama dalam media sosial. Namun seperti semua media pada umumnya, media memiliki kekuatan untuk mempengaruhi masa depan dan cerminan masyarakat (Ibrahim dan Ahmad, 2014:3-5). Terlebih dengan hadirnya new media saat ini, manusia hidup dalam realitas yang berbeda-beda. Mulai dari kehidupan realitas yang nyata, realitas semu, augmented reality, ruang virtual sampai realitas yang dibuat-buat atau disebut juga dengan 
Nalar: Jurnal Peradaban dan Pemikiran Islam

Vol. 2, No. 1, Juli 2018

byperreality (Rosenfeld, 2015:1). Pada tataran ini, siapapun dapat membuat, mengedit, menghapus dan merubah apapun terkait citra dirinya ketika ingin berhubungan dengan masyarakat dalam dunia digital.

Popularitas aplikasi media sosial di Indonesia seperti Instagram menjadikan banyak budaya populer lahir dan ditiru oleh para netizen. Salah satunya fenomena bijabers yang dipopulerkan oleh beberapa perancang busana muslimah. Nama seperti Dian Pelangi, Anniesa Hasibuan dan lainnya adalah sederet nama bijabers lainnya yang terkenal lewat akun media sosial seperti Instagram yang berusaha menuju ke arah tersebut. Melihat defenisi ini peneliti juga melihat bahwa Dian Pelangi lebih banyak berfokus pada satu segmentasi muslimah yang menggunakan hijab atau jilbab saja sebagai daya tarik utamanya. Inilah mengapa lebih tepat dikatakan sebagai micro-celebrity.

Fenomena hijabers ini menarik dikarenakan sebagai muslim ada keinginan menunjukkan perilaku keberagamaannya, namun juga tidak bisa dipungkiri seringkali hijabers tersebut mem-posting diri dengan latar belakang ala Barat sehingga terkesan trendi dan mewah. Terlebih di Indonesia yang merupakan negara muslim terbesar di dunia, menjadikan para hijabers seperti Dian Pelangi ini seakan-akan membuka pengaruhnya di masyarakat. Fenomena serupa sebenarnya juga terdapat di Barat dengan sebutan "bijabista" (Kavakci dan Kraeplin, 2016:850). Namun dengan adanya kepentingan bisnis yang menaungi, identitas yang dibawa menjadi bertumpuk dan publik tidak bisa membedakan mana identitas secara personal sebagai micro-celebrity dan sebagai endorser atau self-branding seperti yang juga terjadi di Barat (Kavakci dan Kraeplin, 2016:855). Ini penting dikarenakan citra diri yang terbentuk sebenarnya mempengaruhi pembawaan para hijabers ini. Sehingga menjadi pertanyaan sebenarnya bagaimana identitas yang dibawa hijabers sebagai microcelebrity dan model endorser, serta ide-ide yang dibawa sebagai seorang hijabers. Terlebih dengan ia meng-update di setiap kegiatannya maka akan terlihat seperti cerita atau self-story layaknya sebuah buku catatan harian.

Instagram pada dasarnya memiliki dua fitur yang memungkinkan seseorang untuk menunjukkan apa yang sedang dilakukannya, yaitu foto dan teks. Kedua fitur tersebutlah yang pada akhirnya digunakan oleh pengguna untuk menceritakan tentang dirinya sendiri seputar kegiatannya. Fenomena mengenai hijabers yang tampil sebagai representasi wanita muslimah ini menarik untuk dikaji dari sisi pembentukan citra diri. Pada titik inilah peneliti tertarik apa dan bagaimana para hijabers membangun percampuran identitas personal dengan identitas diri sebagai market branding. Peneliti juga tertarik tentang bagaimana pembentukan identitas ini dipadukan dengan gambar dan teks yang seolah diceritakan layaknya sebuah diary. Penelitian ini menggunakan metode kualitatif untuk menganalisis temuan. Penelitian ini akan dibedah menggunakan dua teori, yaitu teori identitas untuk melihat citra diri dan teori dramaturgi Erving Goffman untuk membedah bagaimana Dian Pelangi menceritakan keseharian dirinya khususnya lewat instagram.

\section{New Media Dramaturgi Hijabers: Self-story sebagai Presentasi Diri via Instagram}

Banyak studi mengenai identitas yang ditulis berdasarkan teori ini seperti studi mengenai dramaturgi new media, identitas dan cerita diri dalam media digital, dan identitas online dan presentasi diri. Ketiga studi tersebut menjadi gambaran bahwa ada aspek yang menarik untuk mengupas identitas dari presentasi diri atau dramaturgi dalam konteks new media. Pada konteks ini, media baru dan segala bentuknya seperti media sosial diibaratkan seperti panggung. Media tersebut sebagai sisi depan "pertunjukan diri” dan media menjadi sarana bagi semua "atraksi" dipertontonkan ke ranah publik (user).

Dramaturgi sendiri adalah salah satu pendekatan dalam ilmu sosial dalam melihat kepribadian seseorang dari depan. Erving Goffman (1956) menggambarkan bagaimana 
Nalar: Jurnal Peradaban dan Pemikiran Islam

Vol. 2, No. 1, Juli 2018

seseorang membangun diri dalam masyarakat. Menurutnya bahwa seseorang mengorganisasikan hal tersebut bagi masyarakat secara domestik, komersial dan industrial (Goffman, 1956:ii). Terdapat enam proses yang disebut sebagai "performance" atau bagaimana seseorang merepresentasikan dirinya di depan maupun di belakang panggung (Goffman, 1956:13-46) :

\section{Front}

Menurut Goffman (1965), front atau sisi depan merupakan segala hal yang menyangkut performa individu selama ia menjalani lakonnya sebagai aktor. Dalam menggambarkan bagian depan ini, Goffman menggambarkannya seperti sebuah setting panggung yang terdiri atas dekorasi, furniture atau segala hal yang menyangkut fisik (Goffman, 1956:13). Artinya Goffman ingin menunjukkan bahwa sebenarnya bagian depan adalah "topeng" dari segala yang menutupi sifat dari si aktor. Lebih lanjut Goffmann mengatakan bahwa sisi depan merupakan segala hal yang bersifat indah. Ini didasarkan pada sedikitnya jumlah penonton yang mengetahui kehidupan sang aktor di belakangnya (Goffman, 1956:13). Orang akan tertuju kepada sesuatu yang ada di depan karena hal tersebut memang lebih menonjol. Aspek yang indah itulah yang terkadang membuat beberapa orang dapat tertipu atau yang dikenang hanya yang manis-manis jika dikontekskan dalam masyarakat. Hal ini juga berlaku di dalam media di mana dari sisi depan media tersebut tampak baik-baik saja dengan berbagai atribut yang menarik.

Dalam konteks instagram Dian Pelangi, foto kegiatan merupakan dalam pusat dalam self-story yang lebih banyak menggambarkan sisi depan bijabers ini. Foto-foto kegiatan yang selalu ia update dalam akun Instagramnya tersebut merupakan presentasi diri yang ia tampilkan sisi-sisi personalnya. Latar belakang pengambilan gambar seperti tempat, busana, aksesoris, serta hal-hal lain yang menunjang penampilannya merupakan apa yang dikatakan Goffman sebagai scenic aspect of front (Goffman, 1965:13).

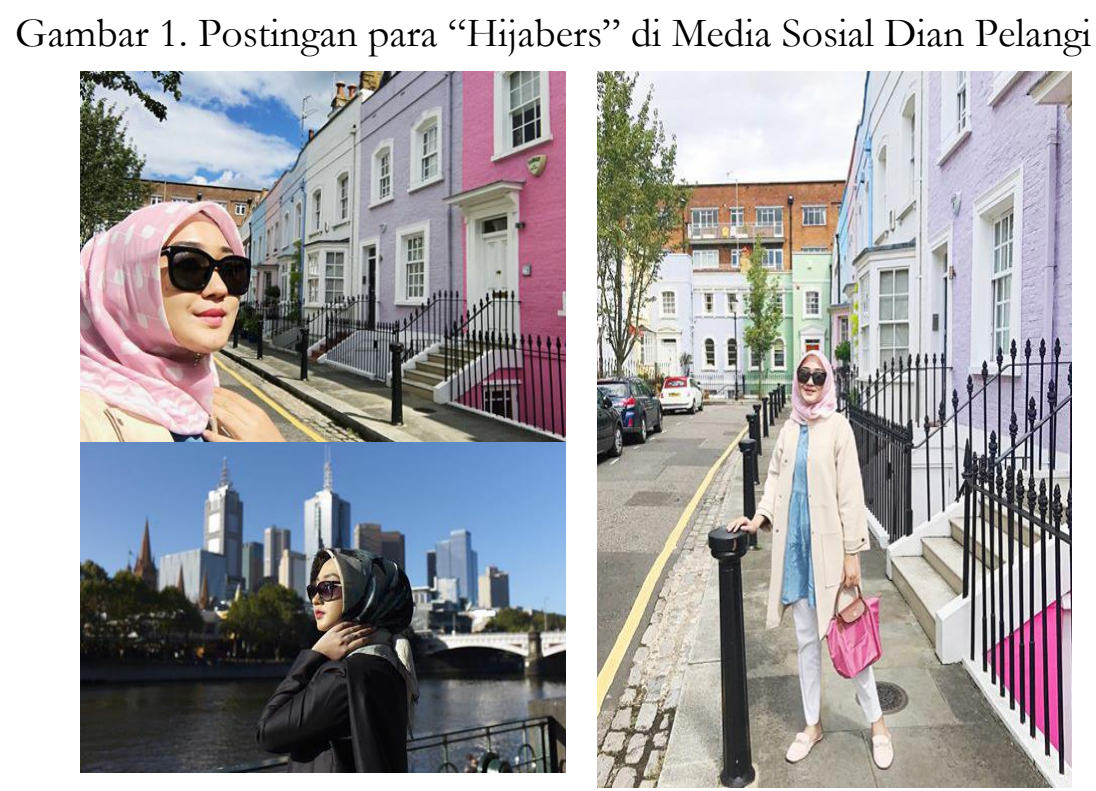

Sumber: Akun instagram @dianpelangi, diakses 27 November 2017

Latar belakang tempat sebenarnya merupakan hal yang paling menonjol dari Dian Pelangi. Latar belakang tersebut seolah merepresentasikan bahwa dirinya secara personal menyukai bepergian dan mengunjungi tempat-tempat ikonik. Dari postingannya kegiatannya mulai dari fashion show hingga kegiatan pribadinya. Selain itu tampak juga bahwa 
Nalar: Jurnal Peradaban dan Pemikiran Islam

Vol. 2, No. 1, Juli 2018

Dian Pelangi pembawaan fisik seperti busana dan aksesori yang dipakainya juga menguatkan kesan-kesan yang indah. Sehingga siapapun yang melihat akun Instagram Dian Pelangi akan melihat ia sebagai muslimah yang sempurna dari sisi depan atau front. Inilah yang lalu juga sulit untuk membedakan apakah hal tersebut merupakan kehidupan pribadinya atau memang ia sedang mempromosikan sesuatu. Tidak terlihat perbedaan signifikan jika melihat gambar-gambar dalam akun Instagram Dian Pelangi.

\section{Dramatic Realization}

Ketika seorang aktor mulai melakukan interaksi dan improvisasi baik di panggung atau dengan penonton, maka selanjutnya adalah bagaimana membuat adegan tersebut terlihat menarik. Goffmann menjelaskan pada bab ini bagaimana seseorang "berharap untuk menyampaikan.. Ekspresi diri yang berusaha ditampilkan juga diharapkan dapat ditiru atau menjadi contoh bagi penonton meskipun itu fiksi maupun non fiksi (Goffman, 1965:20). Namun pada bagian ini penonton tidak dapat melihat tentang bagaimana merancang dramatisasinya mulai dari waktu, cara mendramatisasikan dan sebagainya. Goffman menyebutkan penonton dalam konteks ini dengan istilah eye consumer (Goffman, 1956:21).

Istilah eye consumer pada konteks media baru pada dasarnya masih relevan dengan yang ada dalam kasus bijabers ini. Penonton atau dalam hal ini follower tidak kesemuanya tahu bagaimana pengambilan gambar tersebut dibuat. Namun pesan yang dibuat sangat jelas dengan teks yang tersedia di bagian bawah foto. Sehingga follower dapat dengan mudah mengetahui isi dan tujuan update status Dian Pelangi. Hanya saja dalam tataran ini lebih jelas untuk membedakan antara pesan personal dengan pesan yang bertujuan komersial. Inilah yang membuat dramaturgi dalam ranah new media berbeda dengan pesan yang biasa ditampilkan dalam konteks panggung maupun media lainnya.

\section{Idealization}

Dalam tahap ini Goffmann menggambarkan bahwa aktor mencari penyesuaian setelah latihan dan rutinitas penceritaan. Tujuannya untuk memodifikasi sejumlah aspek agar lebih dipahami penonton dan ekspektasi yang diharapkan dari lingkungan sosial (Goffman, 1956:23). Penyesuaian tersebut dikarenakan pada dasarnya setiap individu di dalam sistem masyarakat terstratifikasi dengan satu sama lainnya. Hal inilah yang mendasari bahwa penyesuaian harus dilakukan agar individu dapat menyuarakan pendapat baik dalam level yang rendah maupun level yang tinggi. Mobilitas antar stratifikasi itulah yang nantinya membantu untuk menentukan bagaimana idealnya seorang individu di masyarakat.

Namun hal ini cukup berbeda di dalam kasus hijabers Dian Pelangi ini. Tidak ada latihan khusus untuk penyesuaian. Hanya terdapat rutunitas penceritaan dan cenderung menunjukkan kelas yang berbeda. Rata-rata posting Dian Pelangi di Instagram lebih banyak bercorak sama, yaitu menampilkan gambar yang sepadan, dalam artian tidak ada perbedaan mencolok. Eksplorasi pribadi adalah yang hal yang umum ditemui dan dikarenakan ia juga merupakan model endorse produk kosmetik, maka penyesuaiannya terletak pada bagaimana gaya hidupnya sehari-hari. Sehingga penyesuaian yang dimaksud lebih banyak untuk menjaring perhatian para followers.

\section{Maintenance of Expressive Control}

Ekspresi atau perilaku yang berusaha ditampilkan individu di media sosial seringkali berbanding terbalik dengan realitas kehidupan sosial. Akibatnya muncul kode-kode di masyarakat yang menunjukkan ketidaksetujuan atau perbedaan atas kenyamanan terhadap individu lainnya. Terkadang juga hal-hal lain seperti ekspresi yang bersifat accidental 
Nalar: Jurnal Peradaban dan Pemikiran Islam

Vol. 2, No. 1, Juli 2018

(kebetulan), dan tidak kehati-hatian muncul. Hal ini didasari karena aktor tidak menjaga konsistensinya dengan baik (Goffman, 1956:33). Oleh karena itu, perlunya kontrol dalam hal ini untuk menjadikan aktor dapat menjaga kesesuaian dirinya dengan baik.

Ketidaksesuaian ini tidak ditemukan oleh peneliti dalam akun Instagram Dian Pelangi. Dalam akun tersebut lebih banyak pada aspek perhatian dan kesempurnaan yang lebih banyak ditonjolkan oleh para followemya. Ini juga merupakan salah satu dimensi perbedaan yang cukup mendasar dalam new media, di mana ekspresi diri dan identitas menjadi terlihat sempurna dan menghasilkan realitas semu yang belum tentu benar-benar menggambarkan personalnya. Sampai penelitian ini ditulis belum ada posting yang bernilai kontroversi dalam akun Instagram hijabers ini. Katakanlah terdapat kritik, hal itu masih terbilang wajar dan tidak sampai mendekati kebencian seperti yang dilakukan para haters di setiap media sosial.

Gambar 2. Kolom Komentar akun Instagram Dian Pelangi

Disukai oleh azizahuwaida dan 33.581 lainnya
dianpelangi Meet me in Paris?
Wearing Alenna dress from @novierock_store
and Good Fortune scarf from Allura Scarf, ALL
available @hijup .com by the way, today is
the last day of Hijup End of Season Sale up to
$70 \%$ soooo hurry up head to hijup.com now!
Make up by @philipekarunia for
@wardahbeauty
Photo by @danihuda
Lihat semua 247 komentar
dianpelangifcsurabaya 8
makeuphijabs Beautiful
30 NovemBER

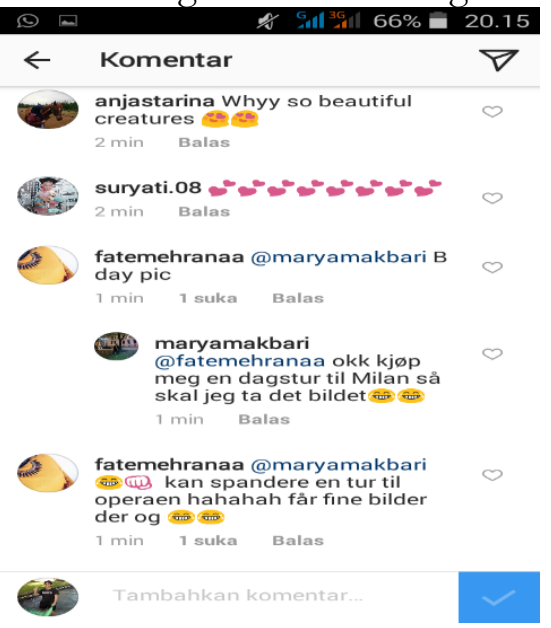

Sumber : akun Instagram @dianpelangi, diakses 17 Desember 2017

\section{Misrepresentation}

Apa yang terjadi di depan panggung (front) tak selalu berkesesuaian dengan apa yang ada di balik panggung. Bahkan sangat dimungkinkan terjadinya kesalahan yang tidak diinginkan. Dalam masyarakat sosial hal tersebut sering kali menimbulkan kesalahpahaman dan tampak sebagai phony (kepalsuan) menurut Goffman (1956). Hal inilah yang disebut Goffmann sebagai misrepresentation atau kekeliruan dalam merepresentasikan sesuatu (Goffman, 1956:37). Namun menurut Goffmann hal tersebut juga tergantung kondisi psikologis masyarakat dalam menentukan antara mana yang valid dan yang tidak. Ini mengingat masyarakat juga memiliki ukuran yang tidak objektif dalam menentukan sesuatu tersebut (Goffman, 1965:38). Pada ranah ini kesalahan dalam new media bergantung kepada followers yang melihatnya. Namun hal ini juga tidak ditemui dalam akun Instagram Dian Pelangi. Kekeliruan yang terjadi tidak nampak, namun bukan berarti tidak bisa terjadi. Ini dikarenakan kondisi psikologis masyarakat yang juga memiliki ukuran tersendiri, hal tersebut juga dapat terjadi di dunia digital sewaktu-waktu.

\section{Mystification}

Goffman (1965) dalam bab ini sebenarnya ingin menerangkan bahwa di dalam panggung, terdapat hal-hal yang membuat audiens bingung kenapa hal tersebut dilakukan. Dalam beberapa hal, adegan tersebut seperti memiliki kekuatan dan misteri yang tersembunyi. Goffman menggambarkan adegan ini seperti sebuah koin yang memiliki dua mata sisi (Goffman, 1965:46). Pada satu sisi audiens merasa bahwa hal tersebut merupakan 
Nalar: Jurnal Peradaban dan Pemikiran Islam

Vol. 2, No. 1, Juli 2018

kekuatan dan misteri rahasia dibalik performa aktor. Serta dari sisi aktornya melihat hal tersebut sebagai "rahasia yang cantik" atau "secrets are pretty ones" . Tidak bisa dipungkiri bahwa bentuk kekaguman para follower terhadap setiap posting Dian Pelangi menunjukkan bahwa sebenarnya kekaguman terhadap sisi-sisi tersebut. Namun dikarenakan hal ini termediasi, para follower ini lebih banyak memuji ketimbang mengeksplorasi apa yang dibawa oleh Dian Pelangi dalam akun Instagramnya.

\section{Computer Mediated Communication Theory}

Computer Mediated Communication (CMC) merupakan bentuk komunikasi yang berbeda dengan bentuk komunikasi lain seperti komunikasi interpersonal, komunikasi organisasi, dan komunikasi massa. seperti yang dinyatakan oleh Andrew F. Wood dan Matthew J. Smith (2004:4), bahwa CMC merupakan suatu integrasi tekhnologi komputer dengan kehidupan sehari-hari. Selain itu, Bagdikian sebagaimana yang dikutip Suparno (2012:90) juga mengatakan bahwa teknologi internet yang merupakan pilar utama dalam bentuk CMC, posisinya masih membingungkan apakah sebagai media massa atau tidak. Ia bagaikan dua sisi mata uang. Pada satu sisi internet tidak terkontrol secara terpusat di dalam memutuskan apa yang akan disebar demi kepentingan publik. Di sisi lain, bentuk komunikasi CMC mendemonstrasikan efek-efek massa dalam pemberitaannya, informasi yang bersifat umum serta dampaknya yang tersebar luas. Dilihat dari teori CMC ini, instagram milik hijabers Dian Pelangi yang sudah bagaikan social diary telah memberikan inspirasi kepada followernya. Hal tersebut dapat berupa gaya berhijab, bagimana cara berpakaian dalam keseharian Dian Pelangi, bahkan sampai gaya hidup yang lain. Dian Pelangi sebagai micro celebrity berusaha menyampaikan pesan islam lewat gaya berpakaian yang ia bagikan lewat akun instagramnya. Pesan yang ingin ia bagikan adalah bahwa muslimah dapat tampil syar'i tanpa terlihat kuno.

\section{Hijab sebagai Identitas: Tinjauan Teoritis dalam Konteks Micro-Celebrity}

Ada banyak teori dan konsep mengenai apa yang disebut identitas. Stephen W. Littlejohn dalam bukunya mendefinisikannya sebagai budaya, masyarakat, relasi dan gambaran individu tentang konsep diri. Identitas juga dinamis dan penuh warna, sehingga identitas membantu personal untuk menjelaskan bagaimana ia mendefinisikan dirinya secara impersonal. Segala aspek yang menyangkut tentang dirinya mulai dari mana ia berasal, mengapa kulitnya berwarna, budaya apa yang ada dirinya hingga kenapa bisa sampai disini dapat didefiniskan sebagai identitas. (Littlejohn, 2009:492-493).

Ada banyak penelitian yang mengulik seputar bagaimana identitas direpresentasikan oleh para micro-celebrity di dunia maya ini mulai dari sebagai identitas brand atau self-branding (Centeno dan Wang, 2017:133; Page, 2012:181; Khamis, Ang dan Welling, 2017:191), fashion religi (Kavakci dan Kraeplin, 2016:850), konsep identitas selebrity di Twitter (Marwick dan Boyd, 2011:139 dan 2010:114), dan selebtwits (Rahmawan, 2014:1). Sedangkan penelitian identitas yang dibangun dalam komentar atau pun medium lainnya lebih banyak menggambarkan transaksi identitasnya seperti pada penelitian mengenai interaksi dengan para followers (Giles, 2017:445; Logan, 2015:378), ideologi (Strafella dan Berg, 2015:352376).

Merujuk pada beberapa penelitian di atas, terdapat beberapa cara identitas dikomunikasikan. Dalam konteks etnik, identitas dikomunikasikan dalam bentuk simbol, norma, dan pelabelan sebagaimana ia mengekspresikan dirinya. Tentu hal yang berbeda bisa ditemui dalam media sosial dimana identitas kerap kali dipertunjukkan dengan bahasa, gambar visual dan lain sebagainya. Karena media sosial juga sebagai bentuk komunikasi offline (tidak langsung) atau virtual, maka terdapat kompleksitas yang diantaranya dapat 
Nalar: Jurnal Peradaban dan Pemikiran Islam

Vol. 2, No. 1, Juli 2018

mempengaruhi negosiasi. Inilah yang membuat definisi mengenai identitas bisa berubah pemaknaan sesuai dengan kompleksitas kasus, fenomena, dan ruang atau dimensinya.

Tabel 1. Model Pembentukan Identitas dalam Akun Instagram Dian Pelangi

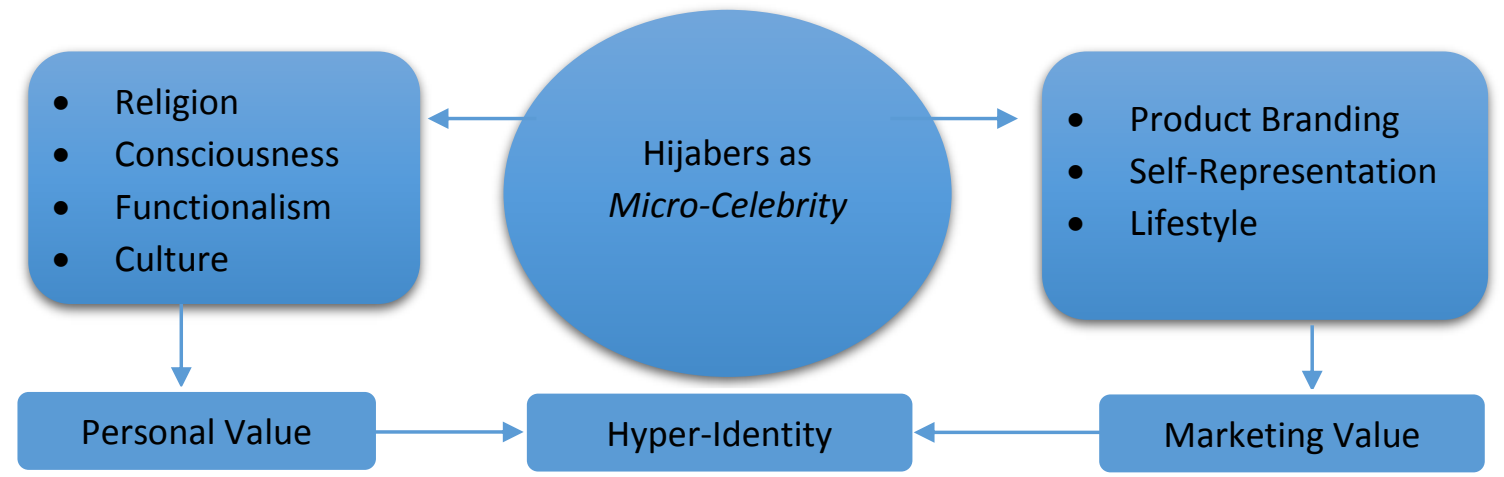

Dalam konteks penelitian ini, hijabers sebagai micro-celebrity memiliki berbagai identitas yang beragam. Namun secara garis besar dapat dibagi menjadi dua, yaitu identitas secara personal dan secara branding. Identitas personal merupakan identitas dasar yang dibangun berdasarkan lingkungan maupun keyakinan di dalam diri seseorang. Unsurnya terdiri atas agama, kepercayaan, segala bentuk fungsional dan budaya. Hal ini biasanya dibentuk oleh kepribadian di dunia nyata yang dibawa dalam ranah dunia maya. Inilah mengapa muncul identitas personal hijabers yang kebanyakan merupakan seorang muslim seperti Dian Pelangi. Segala bentuk hijab merepresentasikan ideologi agama yang dianut oleh pemilik akun Instagramnya. Inilah mengapa hijab baik di dunia nyata maupun dunia maya selalu identik dengan jilbab.

Namun berbeda halnya dengan identitas secara branding, di mana lebih banyak mengeksplorasi sisi gaya hidup bijabers seperti Dian Pelangi. Sisi yang coba dimunculkan dalam ini lebih banyak berkaitan dengan pekerjaan, kegiatan dan segala bentuk nilai yang memiliki nilai jual. Bahkan dalam beberapa hal, pembawaan juga ikut mempengaruhi mulai dari busana, aksesoris hingga produk kosmetik yang dipakai oleh micro-celebrity. Dalam kasus Dian Pelangi ini hal tersebut biasanya dimunculkan dalam foto-foto beserta teks berisi pesan kegiatan. Tidak ketinggalan pula busana yang dipadukan sedemikian rupa yang lebih menunjang aspek modis Dian Pelangi itu sendiri. Sehingga bisa disimpulkan benang merahnya bahwa terdapat realitas yang beragam dan menjadi satu serta seolah-olah tidak bisa dipisahkan atau byper-identity. Ini dikarenakan Dian Pelangi dalam akun Instagramnya memakai banyak identitas yang tersemat, sehingga identitas personal dan self-branding tidak nampak jelas perbedaannya.

\section{Identifikasi Diri}

Identifikasi diri merupakan pemahaman mengenai diri seseorang yang membuat individu sadar akan keunikan diri sehingga akan memberikan arah, tujuan dan makna pada hidup seseorang. Identifikasi diri merupakan suatu proses pengkombinasian pengalaman, kepercayaan, dan identifikasi yang dimiki pada masa kanak-kanak, pada kesatuan yang unik dan akan semakin lebih atau tidak koheren, yang akan memberikan para dewasa perasaan yang berkaitan dengan masa lalu maupun masa yang akan datang. Identifikasi diri sangat penting dilakukan oleh semua orang untuk mengenali diri agar tidak terperosok pada lembah kerusakan diri. Gambaran yang baik tentang diri seseorang perlu dibangun sedini mungkin agar tidak justru menunjukkan keburukan diri. Dengan mengenali diri sendiri, setiap individu akan merasa bahagia karena dapat menerima setiap kekurangan dan 
Nalar: Jurnal Peradaban dan Pemikiran Islam

Vol. 2, No. 1, Juli 2018

kelebihan yang ada pada dirinya, sehingga ia akan melesat maju ke depan tidak terkungkung pada pemikiran klasik tentang standar diri yang ideal.

Dian pelangi sebagai publik figur di dunia sosial media mengidentifikasikan dirinya sebagai sosok muslimah masa kini yang trendi, modis, dan high class. Sebagai publik figur, Dian Pelangi melalui akun instagramnya menstandarkan dirinya sebagai muslimah millenial yang maju dan kekinian. Hal tersebut dapat berdampak positif pada followernya di instagram terutama di kalangan remaja muslim bahwa menjadi islam tidak harus terlihat kuno. Islamic style atau Islamic fashion dapat ditampilkan sesuai perkembangan zaman.

Salah satu cara menutup aurat bagi perempuan muslim adalah dengan berhijab. Namun akhir-akhir ini esensi hijab telah bergeser dari nilai guna sebagai penutup aurat berubah menjadi suatu mode untuk menunjang penampilan. Di media sosial banyak ditemukan adanya hijaber-hijaber yang memberikan tutorial memakai hijab yang modis dan trendi, salah satunya Dian Pelangi ini. Hal ini bisanya dilakukan di sosial media seperti instagram, facebook, maupun yuotube. Selain tutorial tentang hijab, biasanya akun instagram tersebut juga akan menambahkan bagaimana merias wajah yang sesuai dengan tampilan hijab tersebut. Lagi-lagi audience digiring pada standarisasi style tertentu yang salah satunya bahwa yang cantik dan modis adalah yang hijabnya fashionable dan dengan memakai make up.

\section{Konsep Gender dan Penggunaan Hijab sebagai Otonomi Tubuh Perempuan}

Berbicara mengenai gender tentu saja berbicara mengenai usaha emansipasi kaum perempuan. Gender sebagai konsep bertitik tolak pada aspek biologis, yakni gender memiliki dua kategori biologis yakni laki-laki dan perempuan. Setiap kategori baik laki-laki maupun perempuan memiliki makna dan interpretasinya masing-masing dalam masyarakat. Menurut Handayani dan Sugiarti (2006:4), seks adalah pembagian jenis kelamin yang ditentukan secara biologis melekat pada jenis kelamin tertentu. Seks merupakan pembeda antara laki-laki dan perempuan. Perempuan memiliki vagina, payudara, dan alat reproduksi yang berbeda dan laki-laki. Sedangkan laki-laki memiliki penis, jakun, dan lain sebagai nya yang menjadi ciri kodrati dan tidak dapat diubah.

Gender merupakan sifat yang melekat pada laki-laki dan perempuan yang merupakan bentukan dari lingkungan sosial maupun budaya. Bentukan sosial tersebut seringkali cenderung merepresentasikan jika laki-laki adalah makhluk yang kuat, jantan, rasional dan pemberani. Sedangkan perempuan dikenal dengan lemah lembut, keibuan dan cantik. Perempuan tersubordinasikan oleh hal atau faktor yang dikonstruksi secara sosial. Banyak stigma negatif yang menjadikan perempuan posisinya lebih rendah dibandingkan laki-laki. Hal tersebut dikarenakan tubuh perempuan dianggap sebagai ornamen untuk kepuasan kaum laki-laki. Dalam suatu masyarakat dan budaya tertentu, apabila seorang perempuan secara ekonomi lebih rendah dibanding laki-laki, maka ia memiliki keadaan yang inferior dibanding laki-laki. Menurut Bartky, Lee, dan Foucault sebagaimana yang dikutip oleh Benedicta (2011:144) bahwa tubuh perempuan dianggap ornamen, maka penggunaan make up dan pemilihan pakaian semuanya terlibat dalam pemaknaan tubuh perempuan. Membahas mengenai tubuh, tentu saja tidak terlepas dari konsep otonomi atas tubuh.

Otonomi tubuh merupakan upaya sistematis-berkelanjutan dari setiap perempuan untuk mau dan mampu menjadikan tubuhnya otonom, utuh dari penjajahan siapa dan pihak manapun dan di mata siapapun. Hal ini berarti bahwa perempuan memiliki kuasa penuh atas tubuhnya sehingga dirinya bebas menentukan dan independen untuk memaknai realitas yang dihadapinya. Sesuai dengan hal ini maka pemakaian hijab pada muslimah atau hijaber merupakan haknya untuk menentukan bagian tubuh mana yang ingin diperlihatkan dan mana yang tidak boleh diperlihatkan kepada khalayak. Dian pelangi merupakan salah 
Nalar: Jurnal Peradaban dan Pemikiran Islam

Vol. 2, No. 1, Juli 2018

satu figur yang memperlihatkan bahwa wanita berhijab itu merdeka dan dapat berkarya serta berprestasi. Hal ini berbeda dengan zaman dahulu bahwa ruang gerak muslimah berhijab itu terbatas.

Otonomi tubuh perempuan sarat akan kekuasaan. Perempuan dapat dikatakan memiliki kuasa atau otonomi atas tubuhnya saat ia memiliki kontrol penuh terhadap tubuhnya sendiri. Tubuh perempuan khususnya wajah yang memenuhi standar kecantikan di masyarakat akan memberikan keuntungan terhadap perempuan tersebut. Namun tidak semua perempuan memiliki kuasa penuh terhadap tubuhnya sendiri. Ketidakmampuan perempuan untuk menentukan arah tubuhnya dapat terjadi ketika tubuh terutama wajah menjadi komoditas kapitalis dan menjadi keuntungan yang besar.

\section{Kesimpulan}

Self-Story di Instagram memiliki peranan penting seseorang dalam membentuk para micro-celebrity seperti Dian Pelangi ini. Namun dalam perspektif aspek-aspek dramaturgi pembentukan ceritanya terdapat perbedaan terutama dalam aspek misrepresentation. Pertama, para follower lebih banyak akan melihat Dian Pelangi sebagai orang yang sempurna dalam akun Instagramnya dan lebih banyak memujinya. Sementara follower tidak akan tahu masalah apa yang mungkin terjadi lewat akun Instagramnya. Self-story memiliki kekuatan pemanis yang begitu sempurna bagi hijabers seperti Dian Pelangi ini dari segi personal maupun branding-nya. Kedua, dikarenakan identitas yang tumpang tindih antara identitas personal dengan branding, maka identitas yang tercipta lebih menyerupai byper-identity. Memang tidak bisa dipungkiri bahwa Dian Pelangi adalah seorang muslim lewat akun Instagramnya, namun hal tersebut juga berpadu dengan gaya hidup Dian Pelangi yang juga mem-posting kegiatan pribadi maupun membawa nama produk yang ia populerkan. Sehingga follower bisa melihat beragam identitas baik dari tempat, busana, aksesoris, hingga kebiasaannya seharihari. 
Nalar: Jurnal Peradaban dan Pemikiran Islam

Vol. 2, No. 1, Juli 2018

\section{Daftar Pustaka}

Benedicta, Gabriella Devi. 2011. Dinamika Otonomi Tubuh Perempuan antara Kuasa dan Negosiasi atas Tubuh. Masyarakat: Jurnal Sosiologi Vol. 16 No. 2, Juli 2011.

Centeno, Dave dan Wang, Jeff Jianfeng. 2017. Celebrities as human brands: An inquiry on stakeholder-actor co-creation of brand identities. Elsevier, Journal of Business Research Vol. 74 tahun 2017.

Giles, David C. 2017. How do fan and celebrity identities become established on Twitter? A study of 'social media natives' and their followers. Routledge, Celebrity Studies Vol. 8, No. 3 tabun 2017.

Goffman, Erving. 1956. The Presentation of Self In Everyday Life. Edinburgh: University of Edinburgh Social Sciences Research Centre.

Handayani, Trisakti dan Sugiarti. 2006. Konsep dan Teknik Penelitian Gender. Malang: UMM Press.

Ibrahim, I. S dan Akhmad B.A. 2014. Komunikasi dan Komodifikasi: Mengkaji Media dan Budaya dalam Dinamika Komunikasi. Jakarta: Yayasan Pustaka Obor Indonesia

Kavakci, Elif dan Camille R. Kraeplin. 2016. Religious Beings in Fashionable Bodies: The Online Identity Construction of Hijabi Social Media Personalities. Media, Culture, and Society Vol. 39 No. 6, November 2016.

Khamis, S., Ang L. dan Welling R. 2017. Self-branding, 'micro-celebrity' and the rise of Social Media Influencers. Routledge. Celebrity Studies, 2017 Vol. 8, No. 2 tabun 2017.

Littlejohn, Stephen W. dan Foss, Karen. 2009. Encyclopedia of Communication Theory. London: Sage Publications.

Logan, Ashleigh. 2015. Netnography: Observing and Interacting with Celebrity in the Digital World. Routledge. Celebrity Studies, Vol. 6, No. 3 tabun 2015.

Marwick, Alice E. dan Boyd, Danah. 2010. I tweet honestly, I tweet passionately: Twitter users, context collapse, and the imagined audience. Jurnal New Media and Society Vol. 13 No. 1 tahun 2010.

---------. 2011. To See and Be Seen: Celebrity Practice on Twitter. Convergence: The International Journal of Research into New Media Technologies Vol. 17 No. 2 tahun 2011.

Page, Ruth.2012. The Linguistics of Self-Branding and Micro-Celebrity In Twitter: The Role of Hashtags. Jurnal Discourse and Communication Vol. 6 No. 2 tabun 2012.

Rahmawan, Detta. 2014. Selebtwits: Micro-Celebrity Practitioners in Indonesian Twittersphere. Jurnal Kajian Komunikasi Universitas Padjajaran, Volume 2, No. 1, Juni 2014.

Rosenfeld, Kimberly N. 2015. Digital Online Culture, Identity, and Schooling in the Twenty-First Century. New York: Palgrave Macmillan.

Strafella, Giorgio dan Berg, Daria. 2015. The making of an online celebrity: A critical analysis of Han Han's blog. China Information Vol. 29 No. 3 tahun 2015.

Suparno, Basuki Agus, Edwi Arief Sosiawan, dan Sigid Tripambudi. 2012. Computer Mediated Communication Situs Jejaring Sosial dan Identitas Diri Remaja. Jurnal Ilmu Komunikasi Vol. 20 No. 1, April 2012.

Wood, Andrew F dan Matthew J. Smith. 2004. Online Communication: Linking Technology, Identity, and Culture. New York; Routledge.

Pelangi, Dian. 2017. Diakses tanggal 27 November dan 17 Desember 2017 dari https://www.instagram.com/dianpelangi/?hl=id. 